\title{
Employment Opportunities: Building from Nothing Through Creative Solutions
}

\author{
Casmir Onyeneke ${ }^{1, \text { * }}$, Victorhez Edward ${ }^{2}$, Joyce Nwosu $^{3}$ \\ ${ }^{1}$ Department of Statistics, Hezekiah University, Umudi, Nigeria \\ ${ }^{2}$ Department of Computer Science, Hezekiah University, Umudi, Nigeria \\ ${ }^{3}$ Department of English and Literary Studies, Hezekiah University, Umudi, Nigeria
}

Email address:

Casmir.Onyeneke@uopeople.edu (C. Onyeneke)

${ }^{*}$ Corresponding author

\section{To cite this article:}

Casmir Onyeneke, Victorhez Edward, Joyce Nwosu. Employment Opportunities: Building from Nothing Through Creative Solutions. International and Public Affairs. Vol. 3, No. 1, 2019, pp. 1-5. doi: 10.11648/j.ipa.20190301.11

Received: June 17, 2019; Accepted: July 11, 2019; Published: July 23, 2019

\begin{abstract}
Unemployment has become a non-creative menace, which ruins the future of the youths as well as affecting the nations entirely. Unemployment can be terminated through creative solutions leading to employment. Employment is defined as a state which one's work or occupation earns desired income regularly. It is an activity that consumes time in order to generate paid income. Creativity is referred to the ability to come up with an activity, which when implemented gains money for the individual. Globally, companies and industries are insufficient to employ all citizens, because the employment opportunities in these companies only accommodate few citizens. As a result, many can be independently employed through creative solutions and entrepreneurship. Few people managed to create an activity and a solution through thinking, and now, they are being paid for their creativity. This write-up examines the problems of unemployment in Nigeria and proffers a sustainable solution to eradicate the problems. It is pertinent to note that an innovative citizen has all it takes to create, build and develop from the crèche. One of the motivations of this essay is to showcase the various ways of building from nothing through creative solutions. In other words, the steps outlined in this essay take one from the level of unemployment to the position of being an employer.
\end{abstract}

Keywords: Employment, Self-empowerment, Self-employment, Poverty, Corruption, Creativity, Unemployment

\section{Introduction}

It is certain that government cannot provide work opportunities that can serve all the citizens, rather a good government can provide up to fifty percent $(50 \%)$ of opportunities, while a bad government will keep her nation stunted by not providing the core needs of her citizens. Many people have depended on the government's work (white collar jobs); some were favored while others were not [1]. Those that were not favored remained unemployed, relying on nothing to feed or take care of their lives, creating medium of unemployment, which will definitely affect the nation economically, because most of her youths are not employed [2]. Some might engage themselves in stealing, robbery, kidnapping, and other illegal acts.

Creative solutions can be acquired through skill acquisition. One can be motivated from what he learnt from someone either through gatherings, occasions and so on. Examples of sustainable Solutions to the problem of unemployment are to embracing the following create employment opportunities:

Farming has been a creative means of being self-employed by practicing commercial agriculture [3]. Many people do not associate or like to associate with others as a farmer, regarding it as a poor man's job, they prefer running to urban areas for white collar jobs (which will not favor everybody). Farming is not a poor man's job, because, most of wealthy people in the world are also farmers (agriculturist) [4]. Obasanjo has been a farmer, who has ruled Nigeria as a president Farming is not an easy work, it requires physical ability, experience, hoe, cutlass, lake, crops/seed for plantation, and land [5]. These are basic requirements for farming, it does not require millions of money to fend as a 
personal work, rather at a stage you need to buy chemicals for pests and for crop growth as well for their development. Apart from cultivation, we can still have rearing of animals. Rearing of animals provides enough income that can keep an individual in a good state, since it involves fund to buy the animals at their small stage. Some so hunt for the animals for the purpose of rearing without buying. A veterinarian is needed, in order to ensure good state of the animals [6].

Fishing is another aspect of agriculture that involves low cost materials like net, canoe. The most lucrative work of those living around riverside is fishing. Fishing can raise fund for an individual only when punctuality and consistency are practiced. Those living in Niger Delta for instance, dwell much on fishing and were able to fend and train their families and children respectively. Fishing can be affected with chemicals either from companies or individuals, which has the great tendency of killing the aquatic habitats.

Beading is another aspect of creative activity that involves creation of beautified object that can be worn on the neck or on the wrist. Beads are part of ornaments that beautify a being on a dressing code, significantly in African countries. Beading is another means of being self-employed, since many people especially from African countries loves beads. It does not need a huge capital to start up; rather it needs a minor/little capital to afford the beads, thread, pins etc. [7]

Most African markets sell more on beautifiers/ ornaments, due to it nature of choice (being the choice of most Africans). It does not need intensive teaching; it is easy to learn, easy to fund, and an easy way to make money [8]. Hair making and cutting, are works that draws people at least weekly. Hair making (mostly for ladies) is an easy learned work through skill acquisition. Hair making provides much money than we think, because, every lady/ woman in this world loves beautification, and hair making is the major part of beautification. Beautifying shops are among the busiest places, where people troop in and out, in order to be beautified. Hair making involves artificial hairs, thread, needle and other plating materials.

Hair cutting (having a hair cut by a barber) is another means of being self-employed. Most men/boys visits hair cutting shops at least a week, to have their hair cuts with different designs/styles. It requires acquired skill, barbershop, clipper and other hair cutting materials. Eighty percent $(80 \%)$ of barbers are youths, who gains from taking haircuts [9]. Tailoring is another means of being self-employed, through self-empowerment. Tailoring is the act of making, repairing or to alter clothes in a beautiful way. Clothing is among the basis of life we carry out on daily basis. No human that is mentally sound, can do without clothes. Sewing of clothes are done by tailors. Tailoring will raise money for an individual, because, many people sews new clothes with variation in time.

When one has acquired the skills of tailoring he/she has more chance of getting more clients depending on his/her performance, style etc. Having more clients' inclines that he/she will get more money to solve problems and raise fund base on the number of works he/she gets from the client. Many people neglects tailoring as a local work. Tailoring especially in Africa is a great means of being self-employed as well as employing others (which is great aim of being selfemployed: to employ others). It involves a sewing machine, shop, and other necessary equipments or tool.

One can be self-employed by producing cakes, meat pies, egg rolls, car wash, shampoo, perfume, etc. as well selling them in bulk as a commercial dealer. It involves butter, sugar, mixed-fruits, flour, etc.

\section{Methodology - Case Study}

Observing the following Self-employment conditions and its impact on nation's development, using two countries: country A and country B:

a) Country $\mathrm{A}$ has 12 million citizens, all educated and 10 million citizens were employed in companies, while 2 million were neither self-employed nor employed.

b) Country B has 20 million citizens, fifty percent were educated and 5 million were employed by companies, while 10 million were self-employed, others unemployed.

c) Country A has 12 million citizens, forty percent were educated and 2 million citizens were employed by companies, while others were self-employed.

d) Country B has 20 million citizens, eighty percent were educated and 15 million were employed by companies, while 5 million were self-unemployed.

e) Country B has 20 million citizens, eighty percent were educated and 15 million were employed by companies, while 5 million were self-employed.

f) Country A has citizens; 5 million were employed by companies, while other 5 million were not self-employ, waiting for white collar jobs.

g) Country A has 10 million citizens, 5 million were employed by companies and other 5 million were selfemployed.

h) Country B has 8 million citizens, 100, 000 citizens were employed by companies, while 7.9 million were Selfunemployed.

i) Country A has 8 million citizens, 100,000 citizens were employed by companies, while 7.9 million were selfemployed.

j) Country A has 6 million citizens, none where employed as a worker, and as well Self-unemployed.

k) Country B has 6 million citizens, none was employed by companies, but all were self-employed.

1) Country A has 6 million citizens, all were employed by companies, as well no one was self-employed.

\subsection{Ways to Enhance Creativity}

1. Government Contribution: Government has a great role to play in terms of employment issues. Government should contribute effectively in the following dimensions:

a) Provision of employment through creation of job/work opportunities by building more companies for qualified citizens [10]. 
b) Provision of a medium where citizens can acquire skills on different areas. It is certain that not all the citizens will be employed to work in companies or offices, but with the aid of skill acquisition programs many will be empowered to be selfemployed, living independent lives [11].

2. Individual/Personal Contribution: Individual should take a positive decision by attending skill acquisition programs either organized by government or by non-governmental organizations [12]. Instead of an individual staying at home, waiting for white collar job, he/she should attend skill acquisition programs for him/her to be empowered, whereby working as a self-employed person until a white collar job is made available for him/her. Individual should not take skill acquisition programs as unimportant programs, because, he/she does not know tomorrow. Deformed individual is not exempted in acquiring skills, because, deformity is not disability. Every individual should motivate himself /herself, he/she can do it, and as well can still make it and it is not must that it will be a white collar job, because it is clear that, "as our faces are different, so our destinies are.

3. Parents Contribution: Parents are expected to encourage their children to be skilled either from skill acquisition programmers, because no one knows where he/she will find himself/herself tomorrow. Parents should also support their children in terms of raising capitals for their desired work or skill [13].

Finally, government and parents should educate their citizens and children respectively, on the importance of being skilled (self-employed) and not depending on white collar jobs whole heartedly.

\subsection{Things That Leads to Self-Unemployment}

1. Ignorance: When one is not aware of skill acquisition he/she tends to be unemployed. When one is not educated on the importance of being self-employed, he/she remains self-unemployed, making him/her dependent.

2. Laziness: The ability of one running away from work or afraid of work (like tailoring, farming etc) he/she will not be self-employed.

3. Harden Decisions/Belief: When one is not ignorant of skill acquisition, but he/she has made-up his/her mind that he/she will not be self-employed or attend any skill acquisition programs, he/she will still remain unemployed, if not favored to be employed in any company.

4. Lack of Capital: One might be skilled, but due to insufficient or zero capital he/she remains unemployed. Sufficient capital can encourage an individual in starting up a new business idea gotten from selfempowerment or skill acquisition programs [14].

\subsection{Advantages of Self-Employment}

1. Independent: Self-employment brings about an individual being independent. She/he gets income and manages it as well.

2. Country Development: Self-employment will increase the rate of country's development, physically and economically. Individuals depend on their jobs without being paid by government, relieves expenses made by government [15].

3. Reduction in Corruption and Unemployment: Selfemployment has reduced the rate of corruption, in the sense that individuals have works doing, paying much concentration on the growth of their work or business, because, idleness tends to corruption/generation of evil thoughts.

Self-employment has reduced the rate of citizens being unemployed, making the nation more productive.

\subsection{Effects of Self-Unemployment}

1. Increase in the Rate of Corruption: Self-unemployment can lead to different kinds of corruption like robbery (armed/unarmed), kidnapping, human/drug trafficking, stealing and one being fraudulent etc. because of Selfunemployment, exposing them to different types of illegal acts [16].

2. Degradation in the Nation's Economy: When individuals are not empowered waiting for white collar jobs which will not favor everybody, the economy will be stagnant, even degrade in some situation, because most individuals are not productive. When one is not empowered, he/she will face difficulties or hardship due to he/she has no means of earning a living.

3. Dependency: When one is not self-employed he/she will definitely depend on someone to feed and carter for $\mathrm{him} / \mathrm{her}$ [17].

4. Death/Starvation: Due to self-unemployment, death and starvation can be recorded, because the individual cannot feed himself/herself to a point which will definitely result to death.

\section{Result}

Stating the results of the above methods in numerical order, the following were observed.

a) Having 12 million citizens, country A grew economically, but there was increase in rate of corruption, idleness, hardship, hunger, and presence of poverty, with minor record of death.

b) Having 10 million citizens self-employed in country A, the nation grew economically, more productive than method I, but cases of hunger, corruptions etc. were recorded due to 5 million unemployed citizens.

c) Country A recorded no/low case of starvation, death, robbery, etc. and they grew up economically.

d) County B grew economically in one dimension, but cases of robbery, starvation, poverty, etc. were recorded due to unemployed citizens.

e) Country B grew economically, but not to the rate of country A in method III, and much cases were not 
recorded.

f) Country A did not grow economically, because the ratio of employed citizens did not dominate the Selfunemployed ones, and many cases were recorded more than other methods.

g) Country A grew economically in two dimensions and fewer cases were recorded. Fifty percent of creativity was also recorded.

h) Country B drew back drastically in the economy, and many cases of corruption and death were recorded.

i) Country A grew economically in a higher dimension and less cases of corruption were recorded and ninety eight percent of creativity was also recorded.

j) Country A, remained undeveloped with many records of cases involving corruption, death, theft, armed robbery, etc. were made. Country A's economic development, remains at zero level.

k) Country B boosted economically with less record of cases involving corruption, and 100 percent creativity was recorded.

1) Country A grew economically with less cases involving corruption and forty percent of creativity was also recorded.

\section{Discussion}

Self-employment can be achieved through selfempowerment [18]. Self-empowerment is the ability to give oneself energy, permission, confidence, strength and control over something that has benefit [19]. For one to be selfempowered, he/she must carry out the following steps:

1. Self-examination: self-examination is the ability of an individual to settle and evaluate what needs to be done at a particular point in time for optimal engagement. The individual is expected to analyze his/her personal history, encounters, innovations, successful activities, and achievements etc. through what he/she like or detest and as hobby, so that he/she will know his/her area of concentration. e.g. one who often find himself fixing devices will likely have the chance of becoming a technician.

2. Thinking (Creativity): One is expected to think deeply on what type of work or job can do to gain income. From here he will come up with many ideas.

3. Research/Reference: Having many ideas, he is requested to make research on those ideas, as well reference other works or jobs relating to them in order to know how it is done.

4. Cost Analysis: The individual is required to analyze the cost of the job. The list of materials needed for the work, of job should be noted.

5. Motivation/Implementation: Most people feels discouraged when the cost has been made, due to insufficient fund to fend the job or work. One should take the courage, motivation on the new work idea, because nothing good comes easier. It is necessary to invest on the new work idea.

\section{Conclusion}

The result of the simple case analysis shows a clear indication that creativity, self-empowerment and Selfemployment plays a great role in nation's economy and wellbeing of that nation. A nation with much self-employed individuals tends to grow economically and in terms of creativity/innovation than nation with self-unemployed individuals. Self-employment can reduce the rate of corruption, hunger as well eradicate poverty etc. For one to be self-employed, he/she must acquire skills and implement the acquired skills gotten from skill acquisition programs, organized by governments or by non-governmental organizations, or from parent's education.

Finally, the major means of sustainable employment is self-empowerment / Self-employment, which does not required one to be submitting job application letters for vacancies that may or may not exist. Self-empowerment is all about implementing/practicing an acquisition of skills in which one can use to be an employer as well. I strongly recommend that the youths and citizens of our dear country, Nigeria to boost their natural potentials in engaging in skills that could empower them with sustainable live jobs.

\section{References}

[1] Pfeffer, Jeffrey (2018). Dying for a Paycheck: How Modern Management Harms Employee Health and Company Performance - and What We Can Do About It. Harper Business. p. 38. ISBN 978-0062800923.

[2] Lee, Eddy (January 1996). "Globalization and Employment: Is Anxiety Justified?" International Labour Review. 135 (5): 485-98. Archived from the original on 2013-05-16. Retrieved 2017-08-27 - via Questia.

[3] Alao Olakunle. "Principles of Economics", Lagos: Darkol Press and Publishers, 2005.

[4] United Nation Convention rights people with disability. Implementation of the Un Convention on the rights of persons with disabilities (RPD). Part one, report on Ethiopia. 2012; 435 .

[5] National Bureau of Statistics. "Labour Force Survey", March 2009.5.

[6] Stone, Raymond J. (2005). Human Resource Management (5th ed.). Milton, Qld: John Wiley. pp. 412-14. ISBN 978-0470-80403-2.

[7] R. Morphy, "Nigeria: Youth Unemployment, Poverty - a Time Bomb for Country" Leadership, August 208. 5.

[8] Dubin, Robert (1958). The World of Work: Industrial Society and Human Relations. Englewood Cliffs, N. J: Prentice-Hall. p. 213. OCLC 964691.

[9] Markey, Raymond; Hodgkinson, Ann; Kowalczyk, Jo (2002). "Gender, part-time employment and employee participation in Australian workplaces". Employee Relations. 24 (2): 129-50. doi: $10.1108 / 01425450210420884$. 
[10] P. Doreo, "The Nigerian Unemployment Challenge", Africa Report Features, 2013.

[11] A. Njoku and O. Ihugba, "Unemployment and Nigerian Economic Growth (1985-2009). International Association for Teaching and Learning (IATEL)." Proceedings of the 2011 International Conference on Teaching, Learning and Change, 2011.

[12] Adebayo, "Youth Unemployment and National Directorate of Self Employment Programmes". Nigerian Journal of Economics and Social Studies, Volume-41, Issue-01, Page Number (81-102), June 1999.

[13] Ogunrinola, I. O. and Osahbuohien (2010): Globalisation and Employment Generation in Nigeria's Manufacturing Sector (1990-2006). European Journal of Social Sciences; Vol 12, N0. 4; pp. 581-593.5.

[14] Oni, B. (2006). Employment Generation: Theoretical and Empirical Issues. In NSE, Employment Generation in Nigeria: Selected Papers for the 2006 Annual Conference (pp. 11-30). Ibadan: Nigerian Economic Society.
[15] Acocella, Nicola (2007). Social pacts, employment and growth: a reappraisal of Ezio Tarantelli's thought. Heidelberg: Springer Verlag. ISBN 978-3-7908-1915-1.

[16] Anderson, Elizabeth (2017). Private Government: How Employers Rule Our Lives (and Why We Don't Talk about It). Princeton, NJ: Princeton University Press. ISBN 978-0-69117651-2.

[17] Freeman, Richard B.; Goroff, Daniel L. (2009). Science and Engineering Careers in the United States: An Analysis of Markets and Employment. Chicago: University of Chicago Press. ISBN 978-0-226-26189-8.

[18] Wood, Jack M. (2004). Organisational Behaviour: A Global Perspective (3rd ed.). Milton, Qld: Wiley. pp. 355-57. ISBN 978-0-470-80262-5.

[19] Blattman, Christopher; Annan, Jeannie (2016). "Can Employment Reduce Lawlessness and Rebellion? A Field Experiment with High-Risk Men in a Fragile State". American Political Science Review. 110 (1): 1-17. doi: 10.1017/S0003055415000520. ISSN 0003-0554. 